\title{
Analisis Petrofisika dan Penentuan Zona Potensi Hidrokarbon Lapangan "Kaprasida" Formasi Baturaja Cekungan Sumatera Selatan
}

\author{
M. Iqbal Maulana, Widya Utama, dan Anik Hilyah \\ Jurusan Teknik Geofisika, Fakultas Teknik Sipil dan Perencanaan, Institut Teknologi Sepuluh Nopember \\ Jl. Arief Rahman Hakim, Surabaya 60111 Indonesia \\ e-mail:widya@geofisika.its.ac.id
}

\begin{abstract}
Abstrak-Analisis petrofisika pada sumur MI-1, MI-2, MI-3, dan MI-6dilakukan untuk evaluasi parameter petrofisika pada Formasi Baturaja. Identifikasi porositas, kandungan serpih, saturasi air dan permeabilitas dilakukan pada empat sumur. Estimasi kandungan serpih dilakukan dengan menggunakan log Gamma ray, estimasi porositas efektif dilakukan dengan menggunakan gabungan log densitas dan log neutron, Saturasi air dihitung dengan menggunakan persamaan Indonesia, dan permeabilitas dihitung dengan menggunakan persamaan Timur. Setelah parameter petrofisika didapat, pembungkalan (lumping) dilakukan untuk mengetahui ketebalan reservoir bersih dan ditentukan wilayah yang memiliki potensi keterdapatan hidrokarbon. Melalui analisis petrofisika dan pembungkalan didapatkan bahwa ketebalan reservoir bersih (net reservoir thickness) pada sumur MI-1 adalah sebesar 18,44 meter, sumur MI-2 sebesar 9,6 meter, sumur MI-3 sebesar 12,192 meter, dan sumur MI-6 sebesar 7,35 meter
\end{abstract}

Kata Kunci-Analisis Petrofisika, Formasi Baturaja, Log, Reservoar.

\section{Pendahuluan}

A nalisis petrofisika sangat berguna untuk karakterisasi reservoar. Karakterisasi reservoar pada analisis petrofisika dilakukan dengan mempelajari litologi, porositas, saturasi air, dan permeabilitas lapisan batuan di bawah permukaan. Penentuan litologi melalui identifikasi log gamma ray bertujuan untuk membedakan lapisan permeabel atau bukan. Log densitas dan log neutron dapat digunakan untuk menghitung porositas lapisan batuan, dan $\log$ resistivitas digunakan untuk mencari saturasi air lapisan batuan.

Dengan melakukan analisis petrofisika pada formasi geologi dapat diketahui struktur bawah permukaan serta zona potensi hidrokarbon dari lapangan produksi. Namun dalam pengembangan sebuah lapangan, perlu juga diketahui seberapa besar cadangan hidrokarbon yang dapat diperoleh dari lapangan tersebut.

\section{TINJAUAN PUSTAKA}

\section{A. Analisis Petrofisika}

Analisis petrofisik merupakan salah satu proses yang penting dalam usaha untuk mengetahui karakteristik suatu reservoir. Analisa petrofisika diawali oleh perolehan data bawah permukaan melalui proses well logging pada lubang pengeboran.

Untuk melakukan analisa petrofisika diperlukan beberapa parameter penting batuan dalam suatu formasi, diantaranya adalah porositas, satrasi air, shale volume dan permeabilitas.

\section{B. Porositas}

Porositas didefinisikan sebagai perbandingan antara volome batuan yang tidak terisi oleh padatan terhadap volume batuan secara keseluruhan. Log untuk mengukur porositas terutama adalah log densitas, neutron, sonik dan Rxo (Heysse, 1991). Log-log tersebut dapat mengukur parameter tertentu yang kemudian dapat digunakan untuk menghitung porositas. Persamaan untuk menghitung nilai porositas batuan adalah sebagai berikut: PHIT $=$ PHIE + Vsh. $\phi$ Tsh

\section{Permeabilitas}

Permeabilitas merupakan besaran yang digunakan untuk menunjukkan seberapa besar ke mampuan suatu batuan untuk mengalirkan fluida yang terkandung didalamnya. Permeabilitas batuan penting untuk dicari guna mengetahui seberapa efektif batuan tersebut untuk diproduksi. Permeabilitas dapat dihitung menggunakan persamaan Timur sebagai berikut :

$\mathrm{K}=0.136 \times\left[\left(\varnothing \mathrm{e}^{\wedge} 4.4\right) /\left(\right.\right.$ Swirr $\left.\left.^{\wedge} 2\right)\right]$

\section{Saturasi Air}

Saturasi air atau kejenuhan air adalah perbandingan kuantitas (volume) suatu fluida dengan pori-pori batuan tempat fluida tersebut berada. Saturasi merupakan persentase bagian dari suatu pori yang terisi fluida. Karena tidak mungkin ada pori-pori yang kosong oleh fluida (vakum) maka $\mathrm{Sw}+\mathrm{So}+\mathrm{Sg}=1$. Secara umum ada 2 cara untuk menentukan saturasi, yaitu dengan analisis laboratorium atas sampel core dari reservoir, dan dengan log. Dalam penelitian ini, saturasi air dihitung menggunakan persamaan Indonesia sebagai berikut :

$\mathrm{Sw}=\left\{\left[\left(\frac{V s h^{2-V s h}}{R s h}\right)^{\frac{1}{2}}+\left(\frac{\phi \mathrm{e}^{m}}{R w}\right)^{\frac{1}{2}}\right]^{2} R t\right\}^{\frac{-1}{n}}$

\section{E. Kandungan Serpih (Shale Volume)}

Perhitungan Shale Volume adalah menghitung kandungan serpih dalam batuan reservoir dengan memanfaatkan log Gamma Ray. Oleh karena itu, perhitungan volume serpih dilakukan sebagai koreksi pada porositas total sehingga dapat diperoleh porositas efektif batuan reservoir. Perhitungan volume serpih $\left(V_{\mathrm{sh}}\right)$ dapat dilakukan secara linear berdasarkan Log Gamma Ray, berdasarkan persamaan Index Gamma Ray $\left(I_{\mathrm{GR}}\right)$ :

VSHgr $=($ GRlog - GRmatrix $) /($ GRshale - GRmatrix $)$ 


\section{F. Perhitungan Cadangan}

Metode perhitungan volumetrik berdasar kepada persamaan volume, data-data yang menunjang pada perhitungan cadangan hidrokarbon adalah porositas dan saturasi hidrokarbon. Persamaan yang digunakan dalam metode volumetrik adalah sebagai berikut:

$\mathrm{G}=\frac{43560 . \text { Vbulk. NTG. } \phi .(1-\mathrm{Sw})}{\text { Bgi Factor }}$

\section{MetOdOLOGi PENELITIAN}

Secara garis besar, penelitian ini mencakup 3 pokok bahasan penting, yaitu analisis petrofisika, analisis mudlog/core, dan perhitungan cadangan. Berikut adalah diagram alir penelitian :
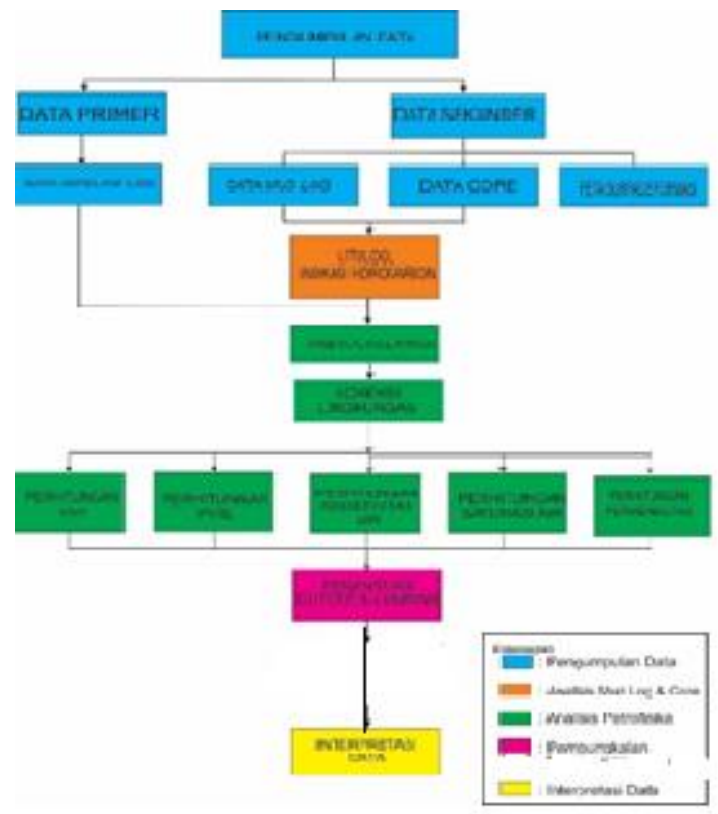

Gambar 1. Diagram Alir Penelitian

\section{HASIL DAN PEMBAHASAN}

\section{A. Porositas Keempat Sumur}

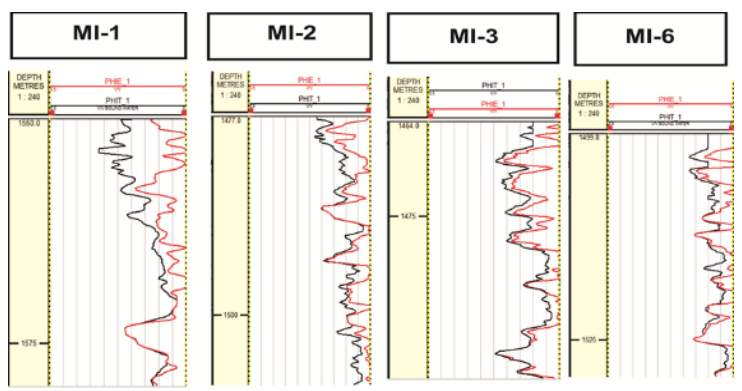

Gambar 2. Tampilan porositas keempat sumur

\section{B. Saturasi Air Keempat Sumur}

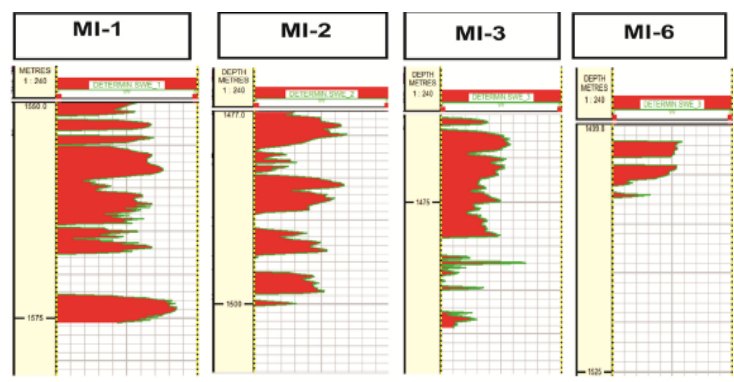

Gambar 3. Saturasi Air keempat sumur

\section{Permeabilitas keempat sumur}

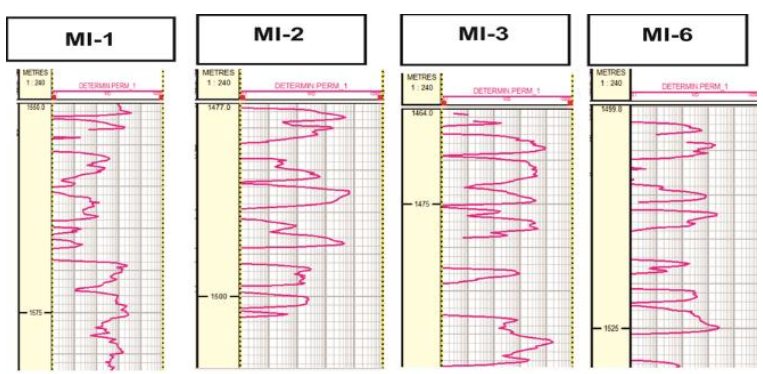

Gambar 4. Permeabilitas keempat sumur

\section{Lumping}

Reservoar yang merupakan zona interest harus memiliki nilai porositas tinggi dan lapisan batuannya permeabel. Zona tersebut harus memiliki kandungan serpih yang sedikit, karena kandungan serpih yang banyak dapat menyebabkan reservoar menjadi kurang produktif. Dalam melakukan lumping, perlu ditetapkan nilai penggal (cutoff) yang berfungsi sebagai filter untuk mendapatkan zona reservoar bersih.

\begin{tabular}{|llccc|}
\hline Top $(\mathrm{m})$ & Base $(\mathrm{m})$ & Gross feet $(\mathrm{m})$ & Net feet $(\mathrm{m})$ & NTG \\
\hline 1550.105206 & 1551.353666 & 1.4298168 & 1.3716 & 0.959 \\
\hline 1552.496666 & 1553.030066 & 1.6764 & 0.6096 & 0.364 \\
\hline 1556.459066 & 1556.687666 & 3.6576 & 0.3048 & 0.083 \\
\hline 1568.955866 & 1571.318066 & 14.6304 & 2.4384 & 0.167 \\
\hline 1572.765866 & 1576.042466 & 4.7244 & 3.3528 & 0.71 \\
\hline 1578.099866 & 1580.766866 & 4.7244 & 2.7432 & 0.581 \\
\hline 1580.995466 & 1581.986066 & 1.2192 & 1.0668 & 0.875 \\
\hline 1582.367066 & 1582.443266 & 0.4572 & 0.1524 & 0.333 \\
\hline 1584.500666 & 1585.796066 & 3.3528 & 1.3716 & 0.409 \\
\hline 1588.005866 & 1590.977666 & 5.1816 & 3.048 & 0.588 \\
\hline 1594.254266 & 1596.159266 & 5.1816 & 1.9812 & 0.382 \\
\hline & \multicolumn{5}{c}{ Gross total =46.234 m } & Net total = 18.44 & NTG rata-rata = \\
\hline & & & 0.495 \\
\hline
\end{tabular}

Gambar 5. Hasil Pembungkalan sumur MI-1

\begin{tabular}{|c|c|c|c|c|}
\hline Top (m) & Base (m) & Gross Feet (m) & Net Feet (m) & NTG \\
\hline 1477.901743 & 1479.04474 & 2.1211032 & 1.2192 & 0.574795229 \\
\hline 1479.730543 & 1480.72114 & 1.6764 & 1.0668 & 0.636363636 \\
\hline 1485.216943 & 1485.29314 & 4.572 & 0.1524 & 0.033333333 \\
\hline 1485.521743 & 1485.90274 & 0.6096 & 0.4572 & 0.75 \\
\hline 1487.045743 & 1488.95074 & 3.048 & 1.9812 & 0.65 \\
\hline 1492.684543 & 1493.97994 & 5.0292 & 1.3716 & 0.272727273 \\
\hline 1508.991343 & 1509.82954 & 15.8496 & 0.9144 & 0.057692308 \\
\hline 1533.375343 & 1533.90874 & 24.0792 & 0.6096 & 0.025316456 \\
\hline 1537.947343 & 1539.24274 & 5.1816 & 1.3716 & 0.264705882 \\
\hline \multirow[t]{2}{*}{1541.147743} & 1541.52874 & 2.286 & 0.4572 & 0.2 \\
\hline & & $\begin{array}{l}\text { ross Total }(m)= \\
4.45\end{array}$ & et Total $(m)=9.6$ & ata-rata = \\
\hline
\end{tabular}

Gambar 6. Hasil Pembungkalan sumur MI-2

\begin{tabular}{|c|c|c|c|c|}
\hline Top (m) & Base (m) & Gross Feet (m) & Net Feet (m) & NTG \\
\hline 1467.231 & 1469.136 & 5.21208 & 1.9812 & 0.380116959 \\
\hline 1469.8218 & 1472.336 & 3.2004 & 2.5908 & 0.80952381 \\
\hline 1473.6318 & 1474.927 & 2.5908 & 1.3716 & 0.529411765 \\
\hline 1476.6798 & 1478.128 & 3.2004 & 1.524 & 0.476190476 \\
\hline 1482.6234 & 1483.157 & 5.0292 & 0.6096 & 0.121212121 \\
\hline 1488.1098 & 1488.643 & 5.4864 & 0.6096 & 0.111111111 \\
\hline 1489.4814 & 1492.301 & 3.6576 & 2.8956 & 0.791666667 \\
\hline 1492.6818 & 1493.215 & 0.9144 & 0.6096 & 0.6666666667 \\
\hline & & $\begin{array}{l}\text { Gross Total }(m)= \\
29.29\end{array}$ & $\begin{array}{l}\text { Net Total }(m)= \\
12.192\end{array}$ & $\begin{array}{l}\text { NTG rata-rata = } \\
0.485\end{array}$ \\
\hline
\end{tabular}

Gambar 7. Hasil pembungkalan sumur MI-3

\begin{tabular}{|ccccc|}
\hline Top $(\mathrm{m})$ & Base $(\mathrm{m})$ & Gross Feet $(\mathrm{m})$ & Net feet $(\mathrm{m})$ & NTG \\
\hline 1504.124906 & 1504.95 & 5.2248816 & 0.9000744 & 0.172 \\
\hline 1505.174942 & 1505.399885 & 0.4498848 & 0.2999232 & 0.667 \\
\hline 1509.67501 & 1510.500103 & 5.0999136 & 0.9000744 & 0.176 \\
\hline 1511.775082 & 1512.59987 & 2.100072 & 0.9000744 & 0.429 \\
\hline 1523.625096 & 1525.349959 & 12.7500888 & 1.8001488 & 0.141 \\
\hline 1534.425074 & 1536.299899 & 10.94994 & 1.9501104 & 0.178 \\
\hline 1541.024909 & 1541.550079 & 5.2498752 & 0.6001512 & 0.114 \\
\hline & & & \multicolumn{3}{c|}{ NTG rata-rata = } \\
& & Gross Total $=41.82 \mathrm{~m}$ & Nettotal $=7.35 \mathrm{~m}$ & 0.26 \\
\hline
\end{tabular}

Gambar 8. Hasil Pembungkalan sumur MI-6 


\section{KESIMPULAN}

Dari penelitian yang dilakukan, dapat ditarik beberapa buah kesimpulan sebagai berikut :

1. Formasi Baturaja Cekungan Sumatera Selatan telah terbukti melalui analisis petrofisika dan perhitungan cadangan memiliki hidrokarbon dengan jenis gas alam dalam jumlah yang melimpah.

2. Penentuan zona hidrokarbon dilakukan melalui analisis data mud log (gas reading, oil show, litologi), wireline log, sidewall core, dan data batuan inti (core).

3. Berdasarkan analisis petrofisika dan pembngkalan (lumping) diketahui bahwa sumur yang memiliki potensi keterdapatan hidrokarbon yang paling baik adalah sumur MI-1

\section{DAFTAR PUSTAKA}

[1] Darling, Toby. 2005. Well Logging and Formation Evaluation. Oxford: Elsevier Publishing Company.

[2] Bishop, Michele G. 2000. "South Sumatra Basin Province, Indonesia: The Lahat/Talang Akar-Cenozoic Total Petroleum System". USGS. http://pubs.usgs.gov/of/1999/ofr-99-0050/OF99$50 \mathrm{~S} /$

[3] Koesumadinata R.P. 1980. "Geologi Minyak dan Gasbumi, Edisi2. Jilid 1 dan 2". Bandung: ITB 